$\begin{array}{ll}\text { Abstracta Iranica } & \begin{array}{l}\text { Abstracta Iranica } \\ \text { Revue bibliographique pour le domaine irano-aryen }\end{array} \\ & \text { Volume } \mathbf{3 0} \mid \mathbf{2 0 1 0} \\ & \text { Comptes rendus des publications de } \mathbf{2 0 0 7}\end{array}$

\title{
Rescuing Afghanistan. London, Hurst \& Company, 2007, 144 p.
}

\section{Anicée Van Engeland}

\section{(2) OpenEdition}

1 Journals

Édition électronique

URL : http://journals.openedition.org/abstractairanica/38175

DOI : 10.4000/abstractairanica.38175

ISSN : 1961-960X

Éditeur :

CNRS (UMR 7528 Mondes iraniens et indiens), Éditions de l'IFRI

\section{Édition imprimée}

Date de publication : 8 avril 2010

ISSN : 0240-8910

\section{Référence électronique}

Anicée Van Engeland, «Rescuing Afghanistan. London, Hurst \& Company, 2007, 144 p. », Abstracta Iranica [En ligne], Volume 30 | 2010, document 335, mis en ligne le 08 avril 2010, consulté le 05 octobre 2020. URL : http://journals.openedition.org/abstractairanica/38175 ; DOI : https://doi.org/ 10.4000/abstractairanica.38175

Ce document a été généré automatiquement le 5 octobre 2020.

Tous droits réservés 


\title{
Rescuing Afghanistan. London, Hurst \& Company, 2007, 144 p.
}

\author{
Anicée Van Engeland
}

L'A. explique que le niveau d'insécurité dans le pays est intense. Il attribue ce climat d'insécurité à l'effondrement des structures administratives dans les années 70, au manque de légitimité des gouvernements qui se sont succédés depuis ces années et à la fragmentation des élites politiques. Il cherche donc dans l'histoire des causes à l'insécurité. Il analyse ensuite les compétitions politiques internes actuelles qui selon lui minent le gouvernement et les chances de l'Afghanistan de se reconstruire.

INDEX

Thèmes : 13.2. Afghanistan

\section{AUTEURS}

\section{ANICÉE VAN ENGELAND}

European University Institute - Florence 